\title{
Effect of Molybdenum on Nodulation, Total Nutrient Uptake and Protein Content of Clusterbean [Cyamopsis tetragonoloba (L.) Taub] Varieties
}

\author{
Arti Yadav", L.R. Yadav and S.S. Yadav \\ Department of Agronomy, S.K.N. College of Agriculture, Jobner, India \\ *Corresponding author:
}

\begin{abstract}
A B S T R A C T
Keywords

Clusterbean,

Varieties,

Molybdenum,

Uptake,

Yield

Article Info

Accepted:

19 April 2017

Available Online:

10 May 2017

A field experiment was conducted at Agronomy farm, S.K.N. College of Agriculture, Jobner (Rajasthan) during kharif, 2015 on loamy sand soil. The twenty treatment combinations consisting of five clusterbean varieties (RGC-936, RGC-1017, RGC-1033, RGC-1002 and RGC-197) and four levels of molybdenum (control, $0.5,1.0$ and $1.5 \mathrm{~kg}$ $\mathrm{Mo} / \mathrm{ha}$ ) were tested in randomized block design with three replications. Results revealed that variety RGC-1033 proved significantly superior to RGC- 936, RGC-1017, RGC-1002 and RGC-197 in respect of total number and dry weight of nodules. Similarly, the seed yield $(1862 \mathrm{~kg} / \mathrm{ha})$ and stover yield $(3821 \mathrm{~kg} / \mathrm{ha})$ were also significantly higher with variety RGC-1033. A significant increase in N, P, K and Mo concentration and their uptake by grain and straw and protein content in seed, were also recorded with variety RGC-1033. Application of $1.0 \mathrm{~kg} \mathrm{Mo} / \mathrm{ha}$ significantly increased fresh and dry weight of nodules. Result showed that molybdenum application at $1.0 \mathrm{~kg} / \mathrm{ha}$ significantly increased seed, stover and biological yield, N, P and Mo concentration in seed and their uptake and protein content in seed. The per cent increase in seed yield with $1.0 \mathrm{~kg} \mathrm{Mo} / \mathrm{ha}$ was 22.1 and 8.0, respectively, over control and $0.5 \mathrm{~kg} \mathrm{Mo} / \mathrm{ha}$. However, application of $1.5 \mathrm{~kg}$ $\mathrm{Mo} / \mathrm{ha}$ remained at par with $1.0 \mathrm{~kg} \mathrm{Mo} / \mathrm{ha}$.
\end{abstract}

\section{Introduction}

Clusterbean [Cyamopsis tetragonoloba (L.) Taub] popularly known as 'guar' is an important legume crop mainly grown under rainfed condition in arid and semi-regions of Rajasthan during kharif season. The crop is grown for different purposes such as vegetable, green manure and seed production. The long deep tap root system enables the plant to grasp all the water available in the soil making it an ultimate drought resistant crop like other legumes and thus offer better scope for rainfed cropping. The crop survives even at moderate levels of salinity and alkalinity.
There is no other legume crop so hardy and drought tolerant as clusterbean, which is especially suited for soil and climate of Rajasthan. Among dryland crops, guar occupies an important place in the national economy because of its industrial importance mainly due to the presence of gum in its endosperm (28 to $32 \%$ ). Clusterbean is a leguminous crop and can fix $37-196 \mathrm{~kg}$ N/ha/year.

In India, clusterbean is mostly grown in Rajasthan, Haryana, Punjab, Uttar Pradesh and Madhya Pradesh. The India's 
contribution is around 75-80 \% in world's total production. India is earning crores of foreign exchange every year by exporting guar gum and a record 11,734 crores were obtained in the year 2014 (Anonymous, 2014). Rajasthan occupies first position in India both in area and production. It accounts for almost 82.1 per cent area and $70 \%$ production in India. Haryana and Gujarat has second and third positions, respectively. Rajasthan has an area of 4.63 million hectare, production of 2.74 million tonnes with a productivity of $593 \mathrm{~kg} / \mathrm{ha}$. (Anonymous 201415). In Rajasthan, guar is mainly grown in Barmer, Churu, Sriganganagar, Nagaur, Jalore, Sikar, Jaisalmer, Bikaner, Jaipur, Jhunjhunu and Alwar districts.

Legume crops require not only adequate macronutrient but also micro nutrient for better growth development and adequate bacterial activity for nodule development. Therefore, an optimum supply of micronutrient under balanced condition is very important for achieving higher productivity. Molybdenum is an important micronutrient leading to poor seed yield of pulses in molybdenum deficient soils. It is an essential component of the enzyme nitrate reductase, which catalyses the conversion of $\mathrm{NO}^{-}$- to NO2-. Molybdenum is a structural component of enzyme nitrogenase which is actively involved in atmospheric nitrogen fixation by root nodule bacteria in leguminous crops. Molybdenum concentrations in legume nodules can be ten times higher than in leaves. It also acts in enzymes, which bring about oxidation reduction reaction, especially the reduction of nitrate to ammonia prior to amino acids and protein synthesis in the cells of plant. Molybdenum is essential for the process of symbiotic and non-symbiotic nitrogen fixation. Molybdenum availability is decreased by application of acid-forming fertilizer such as (NH4)2SO4 to coarsetextured soil.
Therefore, a field experiment has been conducted to assess the effect of molybdenum on nutrient uptake and protein content of different cluster bean varieties.

\section{Materials and Methods}

The experiment was conducted at Agronomy Farm (Plot No. 13) S.K.N. College of Agriculture, Jobner. Jobner is situated $45 \mathrm{~km}$ West of Jaipur at $26005^{\prime} \mathrm{N}$ latitude and 750 $28^{\prime}$ E longitudes and at an altitude of 427 metres above mean sea level in Jaipur district of Rajasthan. The region falls in Agroclimatic zone III-a (Semi-Arid Eastern Plain). The soil was loamy sand in texture, alkaline in reaction $(\mathrm{pH}$ value 8.2), poor in organic carbon $(0.14 \%)$ with low available nitrogen $(130 \mathrm{~kg} / \mathrm{ha})$ and medium in phosphorus and potassium content 16.52 and $151.8 \mathrm{~kg} / \mathrm{h}$, respectively. The average annual rainfall of this tract varies from $350 \mathrm{~mm}$ to $400 \mathrm{~mm}$ and is mostly received during the month of July to September. During summer, temperature may go as high as $48{ }^{0} \mathrm{C}$ while in winter, it may fall as low as $-1.5{ }^{0} \mathrm{C}$. The relative humidity fluctuates between 43 to 87 per cent.

The twenty treatment combinations consisting of five cluster bean varieties (RGC-936, RGC-1017, RGC-1033, RGC-1002 and RGC197) and four levels of molybdenum (control, $0.5,1.0$ and $1.5 \mathrm{~kg} \mathrm{Mo} / \mathrm{ha}$ ) was tested in randomized block design with three replications. The seed was sown manually on July 5, 2015 maintaining spacing of $30 \mathrm{~cm} \times$ $10 \mathrm{~cm}$, with $20 \mathrm{~kg} / \mathrm{ha}$ seed rate. Each plot consisted gross dimension of $4.0 \mathrm{~m} \times 3.0 \mathrm{~m}$ and net area $3.0 \mathrm{~m} \times 1.8 \mathrm{~m}$. The number of root nodules per plant counted at 50 DAS. The seed and straw samples were analyzed separately for nitrogen concentration $(\%)$ by standard (Nessler's reagent) colorimetric method (Snell and Snell, 1949),phosphorus concentration by Vanadomolybdo phosphoric yellow colour method in sulphuric acid 
system (Method No. 60, USDA Hand Book No. 60, Richards, 1954) and Potassium concentration in seed and straw was estimated by flame photometry method (Jackson, 1973). Molybdenum content in seed and was determined by colorimeter (Kotur, 1990) from which molybdenum content (ppm) in sample was determined using ammonium thiocyanate and 1,1-di-isopropyl etc.

\section{Results and Discussion}

\section{Varieties}

It is apparent from data (Table 1) that different varieties of clusterbean differed significantly in producing total number of nodules per plant. The maximum total number of nodules and effective nodules per plant was obtained with RGC-1033 which was significantly superior to RGC-197, RGC1002, RGC-936 and remained at par with RGC-1017.

Variety RGC-1033 being at par with RGC936 and RGC-1017 recorded significantly higher fresh weight (mg/plant) of nodules over RGC-1002 and RGC-197. The per cent increase in fresh weight of nodules in variety RGC-1033 was 12.3 and 7.7 per cent, respectively, over RGC-197 and RGC-1002. However, variety RGC-1033 recorded significantly higher dry weight over RGC936, RGC-1017, RGC-1002 and RGC-197. Rawat et al., (2015), Solanki (2015). Further, variety RGC-1033 produced significantly higher seed, stover and biological yield than RGC-936, RGC-1017, RGC-1002 and RGC197 (Table 1). The later one variety was found poor yielder because of unbranched and poor growth and canopy makeup. The results of the present investigation are in close conformity with findings of other workers namely, Choudhary et al., (2004), Bhutter and Aggarwal (2006), Ayub et al., (2010), Pathak et al., (2010), Kumar et al., (2012), Satyavathi et al., (2014), Rawat et al., (2015) and Solanki (2015).

Data (Table 2) showed that total nitrogen uptake was found significantly higher under variety RGC-1033 (114.15 kg N/ha) which was significantly higher over RGC-197, RGC-1002, RGC-936 and RGC-1017 registering an increase of 82.5, 29.0, 21.0 and 14.8 per cent, respectively. Further, total phosphorus and potassium uptake by clusterbean variety RGC-1033 was significantly higher over RGC-197, RGC1002, RGC-936 and RGC-1017.The maximum uptake of molybdenum was found in variety RGC-1033 which showed significant increase of $84.1,31.0,19.7$ and 15.0 per cent over RGC-197, RGC-1002, RGC-936 and RGC-1017, respectively. A reference to data in table 2 indicated that protein content in seed was not significantly influenced due to different varieties of clusterbean. The results of the present investigation are in close conformity with findings of other workers namely, Rawat et al., (2015) and Solanki (2015).

\section{Molybdenum}

Application of $1.0 \mathrm{~kg} \mathrm{Mo} / \mathrm{ha}$ being at par with $1.5 \mathrm{~kg} \mathrm{Mo} / \mathrm{ha}$, significantly increased total number of nodules and effective nodules per plant as compared to no molybdenum and 0.5 $\mathrm{kg} \mathrm{Mo/ha} \mathrm{(Table} \mathrm{1).} \mathrm{Further,} \mathrm{application} \mathrm{of}$ $1.0 \mathrm{~kg} \mathrm{Mo} / \mathrm{ha}$ significantly increased fresh weight (mg/plant) of nodules as compared to control and $0.5 \mathrm{~kg} \mathrm{Mo} / \mathrm{ha}$ by 11.9 and 6.0 per cent, respectively, table 1 indicated that application of $1.0 \mathrm{~kg} \mathrm{Mo} / \mathrm{ha}$ recorded significantly higher dry weight of nodules over control and $0.5 \mathrm{~kg} \mathrm{Mo} / \mathrm{ha}$ to the tune of 10.5 and 7.2 per cent, respectively. However, it was found at par with $1.5 \mathrm{~kg} \mathrm{Mo} / \mathrm{ha}$. Application of $1.0 \mathrm{~kg} \mathrm{Mo} / \mathrm{ha}$ increased seed yield by 22.1 and 8.0 per cent, respectively, over control and $0.5 \mathrm{~kg} \mathrm{Mo} / \mathrm{ha}$. 
Table.1 Effect of molybdenum application on number and weight of nodules, seed yield and straw yield of clusterbean varieties

\begin{tabular}{|c|c|c|c|c|c|c|}
\hline \multirow[t]{2}{*}{ Treatments } & \multicolumn{2}{|c|}{ Nodules/ plant } & \multicolumn{2}{|c|}{$\begin{array}{l}\text { Weight of effective } \\
\text { nodules } \\
\text { (mg/ plant) }\end{array}$} & \multirow{3}{*}{$\begin{array}{l}\text { Seed } \\
\text { yield } \\
(\mathrm{kg} / \mathrm{ha})\end{array}$} & \multirow{3}{*}{$\begin{array}{l}\text { Straw yield } \\
(\mathrm{kg} / \mathrm{ha})\end{array}$} \\
\hline & Total & Effective & Fresh & Dry & & \\
\hline Varieties & & & & & & \\
\hline RGC-936 & 23.3 & 16.5 & 62.3 & 31.1 & 1477 & 3544 \\
\hline RGC-1017 & 24.5 & 16.8 & 62.4 & 33.1 & 1580 & 3531 \\
\hline RGC-1033 & 25.4 & 17.3 & 63.0 & 35.6 & 1862 & 3821 \\
\hline RGC-1002 & 23.2 & 15.5 & 58.5 & 29.7 & 1382 & 3434 \\
\hline RGC-197 & 22.9 & 14.6 & 56.1 & 28.1 & 1072 & 2167 \\
\hline SEm \pm & 0.6 & 0.3 & 1.3 & 0.8 & 40 & 105 \\
\hline $\mathrm{CD}(\mathrm{P}=0.05)$ & 1.7 & 1.0 & 3.9 & 2.3 & 116 & 302 \\
\hline \multicolumn{7}{|c|}{ Molybdenum(kg/ha) } \\
\hline Control & 21.7 & 14.8 & 56.2 & 29.6 & 1278 & 2938 \\
\hline 0.5 & 22.2 & 15.2 & 59.4 & 30.5 & 1444 & 3209 \\
\hline 1.0 & 25.6 & 17.1 & 62.9 & 32.7 & 1560 & 3482 \\
\hline 1.5 & 26.1 & 17.4 & 63.4 & 33.4 & 1614 & 3569 \\
\hline SEm \pm & 0.5 & 0.3 & 1.2 & 0.7 & 36 & 94 \\
\hline $\mathrm{CD}(\mathrm{P}=0.05)$ & 1.5 & 0.9 & 3.4 & 2.1 & 103 & 270 \\
\hline $\mathrm{CV}(\%)$ & 6.7 & 6.0 & 6.2 & 7.1 & 8.1 & 8.9 \\
\hline
\end{tabular}

Table.2 Effect of molybdenum application on total nutrient uptake and protein content of clusterbean varieties

\begin{tabular}{|c|c|c|c|c|c|}
\hline \multirow{2}{*}{ Treatments } & \multicolumn{4}{|c|}{ Total nutrient uptake by grain and straw } & \multirow{2}{*}{$\begin{array}{l}\text { Protein } \\
\text { content }(\%)\end{array}$} \\
\hline & $\begin{array}{c}\mathrm{N} \\
(\mathrm{kg} / \mathrm{ha})\end{array}$ & $\begin{array}{c}\mathrm{P} \\
(\mathrm{kg} / \mathrm{ha})\end{array}$ & $\begin{array}{c}\mathrm{K} \\
(\mathrm{kg} / \mathrm{ha})\end{array}$ & $\begin{array}{c}\text { Mo } \\
\text { (g/ha) }\end{array}$ & \\
\hline \multicolumn{6}{|l|}{ Varieties } \\
\hline RGC-936 & 94.30 & 10.58 & 46.58 & 11.44 & 25.29 \\
\hline RGC-1017 & 99.42 & 11.14 & 47.24 & 11.91 & 25.54 \\
\hline RGC-1033 & 114.15 & 12.97 & 52.32 & 13.70 & 25.66 \\
\hline RGC-1002 & 88.47 & 9.66 & 44.56 & 10.46 & 25.16 \\
\hline RGC-197 & 62.56 & 6.25 & 29.16 & 7.44 & 24.60 \\
\hline SEm \pm & 2.49 & 0.32 & 1.14 & 0.32 & 0.79 \\
\hline $\mathrm{CD}(\mathrm{P}=0.05)$ & 7.14 & 0.92 & 3.28 & 0.92 & NS \\
\hline \multicolumn{6}{|c|}{ Molybdenum (kg/ha) } \\
\hline Control & 74.35 & 7.62 & 38.30 & 8.97 & 22.88 \\
\hline 0.5 & 86.05 & 9.65 & 42.69 & 10.52 & 24.00 \\
\hline 1.0 & 100.93 & 11.14 & 46.71 & 11.95 & 26.75 \\
\hline 1.5 & 105.78 & 12.08 & 48.20 & 12.51 & 27.38 \\
\hline $\mathrm{SEm} \pm$ & 2.23 & 0.29 & 1.02 & 0.29 & 0.71 \\
\hline $\mathrm{CD}(\mathrm{P}=0.05)$ & 6.39 & 0.83 & 2.93 & 0.83 & 2.02 \\
\hline $\mathrm{CV} \%$ & 7.53 & 8.83 & 7.21 & 8.13 & 8.65 \\
\hline
\end{tabular}


The results on seed and straw yields thus confirmed the trend observed in growth and yield attributing characters with application of molybdenum, Shivkumar amd Kumutha (2003), Togay et al., (2008), Valenciano et al., (2011), Gupta et al., (2012), Khan et al., (2014) and Manohar (2014) also observed significant improvement in yield attributes and yield of different crops due to application of molybdenum.

Molybdenum application at $1.0 \mathrm{~kg} / \mathrm{ha}$ significantly improved the uptake of nitrogen and registered an increase of 35.7 and 17.2 per cent over control and $0.5 \mathrm{~kg} / \mathrm{ha}$, respectively, thereafter, increase in level of molybdenum had no significant effect. Molybdenum application at $1.5 \mathrm{~kg} / \mathrm{ha}$ significantly improved the uptake of phosphorus over control, 0.5 and $1.0 \mathrm{~kg}$ $\mathrm{Mo} /$ ha, respectively. Whereas, molybdenum application at $1.0 \mathrm{~kg} / \mathrm{ha}$ significantly improved the uptake of potassium over control and $0.5 \mathrm{~kg} / \mathrm{ha}$, respectively. Thereafter, increase in level of molybdenum had no significant effect on total K uptake by cluster bean. Table 2 further showed that molybdenum application significantly increased the uptake of molybdenum wherein $1.0 \mathrm{~kg} \mathrm{Mo} / \mathrm{ha}$ registered an increase of 33.2 and 13.6 per cent over control and $0.5 \mathrm{~kg} / \mathrm{ha}$, respectively. The application of $1.5 \mathrm{~kg} \mathrm{Mo} / \mathrm{ha}$ remained statistically at par with $1.0 \mathrm{~kg}$ $\mathrm{Mo} / \mathrm{ha}$. Protein content in seed of cluster bean was also influenced significantly with molybdenum fertilization. Application of 1.0 $\mathrm{kg} \mathrm{Mo} / \mathrm{ha}$ as soil application being at par with $1.5 \mathrm{~kg} \mathrm{Mo} / \mathrm{ha}$ significantly increased the protein content in seed registering an increase of 17.0 and 11.5 per cent over control and 0.5 $\mathrm{kg} \mathrm{Mo/ha}$. The increase in protein content is attributed to more nitrogen fixation and more nitrogen concentration in seed under the influence of applied molybdenum. The results are in close conformity with the findings of Laltanmawia et al., (2004), Raut et al.,
(2004), Bhagiya et al., (2005), Patel et al., (2006), Gad and Kandil (2013) and Manohar (2014).

\section{References}

Anonymous. 2014. Guar gum export APEDA, Guar gum export data, 2014.

Anonymous. 2014-15. Vital Agriculture Statistics, State level summary of Principal crops in Rajasthan, Directorate of Agriculture, Jaipur, Pant Krishi Bhawan, Jaipur, Rajasthan.

Ayub, M., Tahir, M., Nadeem, A., Zubair, M.A., Tariq, M. and Ibrahim, M. 2010. Effect of nitrogen application on growth, forage yield and quality of three cluster bean varieties. $J$. Life and Social Sci., 8(2): 111-116.

Bhagiya, S.R., Polara, J.V. 2005. Effect of boron and molybdenum on yield, quality and nutrient absorption by groundnut. $A d v$. Plant Sci., 18(11): 803-806.

Bhuttar, G.S. and Aggarwal, N. 2006. Evaluation of different genotypes of clusterbean [Cyamopsis tetragonoloba (L.)] for yield and quality characters. Crop Res., 31(3): 399-400.

Choudhary, A.K., Majumdar, V.L. and Shekhawat S.S. 2006. Evaluation of cluster bean genotypes for cultivation in summer season. National Symposium on Arid Legumes for Sustainable Agriculture, Pp.52.

Gad, N. and Kandil, H. 2013. Evaluate the effect of molybdenum and different nitrogen levels on cowpea (Vigna anguiculata). J. Appl. Sci. Res., 9(3): 1490-1497.

Gupta, S.C. and Gangwar, S. 2012. Effect of molybdenum, iron and microbial inoculants on symbiotic traits, nutrient uptake and yield of chickpea. J. Food Legumes, 25(1): 45-49.

Jackson, M.L. 1973. Soil Chemical Analysis. Prentice Hall of India Pvt. Ltd., New Delhi, Pp.498.

Khan, N., Tariq, M., Ullah, K., Muhammad, D., Khan, I., Rahatullah, K., Ahmed, N. and Ahmed, S. 2014. The effect of molybdenum and iron on nodulation, nitrogen fixation and yield of chickpea genotypes (Cicer arietinum L.). J. Agri. Vet. Sci., 1: 63-79. 
Kotur, S.C. 1990. Mo nutrition of cauliflower as affected by Mo application and liming on an acid sandy loam soil. J. Indian Society of Soil Sci., 38(2): 280.

Kumar, P., Yadav, V.K., Yadav, A., Saini, L.K., Yadav, J.S. and Kumar, K. 2012. Performance of cluster bean cultivars under different resource conservation techniques. Environ. Ecol., 30(3): 734-738.

Laltanmawia, L., singh, A.K. and Sharma, S.K. 2004. Effect of phosphorus and molybdenum on yield, protein content by soybean on acid soil of Nagaland. J. Indian Society of Soil Sci., 52: 199-202.

Manohar, M.S. 2014 Effect of sulphur and molybdenum on growth and productivity of fenugreek. M.Sc. Thesis, SKNAU, Jobner.

Patel, B.D., Patel, V.J. and Meisuriya, M.I. 2006. Effect of FYM, molybdenum and weed management practices on weeds, yield attributes and yield of chickpea. Indian $J$. Weed Sci., 38(3/4): 244-246.

Pathak, R., Singh, S.K., Singh, M. and Henry, A. 2010. Performance and Stability of Cyamopsis tetragonoloba (L.)Taub Genotypes under rainfed conditions. Indian J. Dry land Agri. Res. Develop., 25(2): 8290.

Raut, S.S., Chore, C.N., Deotale, R.D., Waghmare, H.U., Hatmode, C.N. and Yenprediwar, M.D. 2004. Response of seed dressing with biofertilizers and nutrient on chemical, biochemical, yield and yield contributing parameters of soybean. J. Soils and Crops, 14: 66-70.

Rawat, U., Rajput, R.L., Rawat, G.S., and Garg, S.K. 2015. Effect of varieties and nutrient management on growth, yield and economics of clusterbean (Cyamopsis tetragonoloba L.). Res. Crops, 16(1): 6467.

Richards, L.A. 1954. Diagnosis and improvement of saline and alkaine soils. USDA Hand book No. 60, Oxford and IBH Pub. Co. New Delhi.

Satyavathi, P., Vanaja, M. Reddy A., G.K., and Vagheera, P., Kumar, V. G., Vaidya, S., Sowmya, P. 2014. Identification of suitable guar genotypes for summer season of semiarid region. Int. J. Appl. Biol. Pharmaceutical Technol., 5(4): 71 -73.

Shivakumar, U.I. and Kumutha, K. 2003. Effect of Rhizobium and molybdenum on nodulation yield and yield contributing characters of groundnut. J. Ecobiol., 15: 451-455.

Solanki, R.B. 2015. Effect of foliar application of iron on clusterbean [Cyamopsis
[Cy. tetragonoloba (L.) Taub] varieties. M.Sc. Thesis, SKNAU, Jobner.

Togay, Y., Togay, N. and Dogan, Y. 2008. Research on the effect of phosphorus and molybdenum applications on the yield and yield parameters in lentil (Lens culinaris Medic.). African J. Biotechnol., 7(9): 12561260.

Valenciano, J.B., Boto, J.A. and Marcelo, V. 2011. Chickpea (Cicer arietinum L.) response to zinc, boron and molybdenum application under field conditions. New Zealand J. Crop and Horticultural Sci., 39(4): 217-229.

\section{How to cite this article:}

Arti Yadav, L.R. Yadav and Yadav, S.S. 2017. Effect of Molybdenum on Nodulation, Total Nutrient Uptake and Protein Content of Clusterbean [Cyamopsis tetragonoloba (L.) Taub] Varieties. Int.J.Curr.Microbiol.App.Sci. 6(5): 1939-1944. doi: https://doi.org/10.20546/ijcmas.2017.605.215 